\title{
Troubling" Thrillers: Between Politics and Popular Fiction in the novels of Benedict Kiely, Brian Moore and Colin Bateman ${ }^{1}$
}

\author{
Marisol Morales-Ladrón
}

Universidad de Alcalá

Copyright (c) 2006 by Marisol Morales-Ladrón. This text may be archived and redistributed both in electronic form and in hard copy, provided that the author and journal are properly cited and no fee is charged for access.

\begin{abstract}
Since the beginning of the Northern Ireland "Troubles", interest in exploring the social and political concerns of a region affected by sectarian violence and religious bigotry has produced a significant body of literary works within which the thriller has become one of the most suitable forms of expression. The traditional action thriller has acquired in this context a rich political dimension, producing what is now widely known as the "Troubles" thriller. The development of this mode has diverged into two categories: the "Troubles-trash"; and a more "literary" form, which draws on serious political matters to reflect upon social and religious disputes. Both kinds, however, have been criticised for offering a stagnant and reductive version of the dynamics of the conflict; a judgement that should be qualified. Bearing this in mind, the purpose of the present article is to analyse the ways in which these issues are echoed in the literary productions of three well-known writers: Benedict Kiely, Brian Moore and Colin Bateman. ${ }^{2}$
\end{abstract}

Key Words: Troubles, thriller, detective, Northern Ireland politics, identity, Benedict Kiely, Brian Moore, Colin Bateman

Yet, in a sense, it is hardly surprising that the climate of Northern Ireland should be a thriller writer's dream. It provides the perfect setting for a thriller and all the necessary ingredients are available in abundance. Northern Ireland is, after all, a place of 'dangerous passion'. (Pelaschiar 1998: 19)

Since the outbreak of the Northern Irish "Troubles" in the late sixties, ${ }^{3}$ interest in exploring the social and political concerns of a region affected by sectarian violence and religious bigotry has produced a significant body of literary works within which the popular genre of the thriller has become one of the most suitable forms of expression. Action, suspense and psychological thrillers have acquired in this context a rich political dimension that intersects inevitably with

ISSN 1699-311X questions of identity, producing the so-called "Troubles" thriller. The development of this mode has diverged into two categories. These are the "Troubles-trash", an extremely popular form that, according to Eve Patten, has become one of the most profitable industries in Northern Ireland since the beginning of the conflict (1995: 128-29), and a more "literary" type, which draws on serious political matters to reflect upon social and religious disputes that cut across national and cultural identities. Both kinds, however, have been strongly criticized for offering a stagnant and reductive version of the dynamics of the "Troubles", one that bases its premises on clear-cut boundaries between opposing poles with regard to nationality, religion or politics. The purpose of this article is to analyse the ways in which these identity issues are echoed in three novels written by the renowned Benedict Kiely, Brian Moore and Colin Bateman, respectively. 
Despite the fact that not all critics would consider the thriller an independent fictional category and would often include it under umbrella terms such as "crime", "detective", "mystery", "suspense" or even "horror" fictions (Glover 1989: 73; Williams 1992: 144 and 195), ${ }^{4}$ differences among these modes abound. Although it is not my intention to explore conceptual considerations in depth, I think it would be helpful to distinguish some of the basic traits that characterize each mode. Crime novels in general share particular features that could be thus summarised: the construction of complex plots; the repetition of fixed patterns that are familiar to the reader; the use of type characters; the inclusion of elements of mystery, so that reading becomes a process of discovery; and the exploration of the conflict between good and evil or integrity and corruption, among some others. More particularly, conventional detective fiction has been defined as "a literature of social and psychological adjustment" whose main objective is to "provide reassurance: mysteries are dissipated, crimes cleared up, evil is punished, order restored, and endings satisfy. The experience of reading is one of recuperation, confirming us in the moral universe we know" (Glover 1989: 67-68). As a result, the process of detection undertaken by the investigator and the final defeat of crime have traditionally endowed the mode with a conservative ideology. Though similar to a certain extent, the thriller is organised around specific milieus, characters and situations, rather than around a method of presentation, "in other words, its constitutive character is in its themes ... it is around these few constants that the thriller is constituted: violence, generally sordid crime, [and] the amorality of the characters" (Todorov 1988: 162). In contrast to the ideology underpinning detective novels with their resolution of the crime and protection of society, the thriller mirrors anarchy, horror and destruction. According to Palmer, "the thriller is based upon the description of deviant acts - murder, rape, burglary, espionage .... The manner in which the description of deviant acts contributes to a consensual view of the world can only be understood on the basis of an analysis of the ideology proposed by the thriller" (1989: 187).

It should not come as a surprise then that a mode that has been defined as "the resolution of a mystery in circumstances of physical danger and energetic activity" (Davies 1989: 123) has developed in particular in Northern Irish writing, trying to reflect the violent atmosphere of the "Troubles", even to the extent of overshadowing other kinds of crime fiction. In fact, scholars almost unanimously acknowledge the thriller as the most popular form in Northern Irish literature (Bowyer-Bell 1978: 22; Rolston 1989: 41; Jeffery and O'Halpin 1990: 115 n. 27; Graham-Yooll 1994: 290; Patten 1995: 128-29; Corcoran 1997: 162; Kelly 2000: 109). Furthermore, the political upheaval of the last four decades has favoured the emergence of a new subcategory, the "Troubles" thriller, which, according to Gerry Smyth, is characterised by the inclusion of stereotyped characters, voyeuristic violence and melodrama (1997: 114). The list of "Troubles" thrillers published in the last thirty years is certainly impressive. ${ }^{5}$ However, as already suggested, not all "Troubles" thrillers fall within the same category. McMinn distinguishes between the documentary type, organised around a predictable pattern that displays the conflict between the IRA and the State, ${ }^{6}$ and novels that include some elements of the thriller but in which a love-story serves as the point of departure from which the sociopolitical conflict becomes a threat to the individual (1980: 114). Bowyer-Bell's assessment is more negative since, for him, the main objective of the thriller is to entertain rather than to teach (1978: 22). In the same vein, neither Rolston (1989: 41) nor Graham-Yooll (1994: 290) include the thriller under the label of "literature". What these critics are referring to is the sensationalist journalistic thriller, the "Troubles-trash" that has inundated publishing houses since the outbreak of the "Troubles", offering a stereotypical and reductive vision of a society divided in two monolithic identities and trying, as Kelly suggests, to give "appropriate form to national and historical experience" (2000: 109). ${ }^{7}$

When we turn to focus on the more "literary" kind we encounter in particular a type of thriller that includes the motive of the operation by proxy - this being "the practice of hostage-taking and the coercion of civilians into delivering car-bombs" (Sampson 1998: 276). This type of manoeuvre is found in Benedict Kiely's Proxopera (1977), Brian Moore's Lies of Silence (1990) and Colin Bateman's Divorcing Jack (1995). The three novels exemplify different facets of the 
Northern Irish reality as perceived by both the Catholic and Protestant sides, oscillating between an interest in the individual and a focus on society, covering different social classes and settings, and shifting from a serious to a more comic tone. Stylistically, these novels conform to the popular form of the thriller in its closed patterns, formulaic structure and predictability, and from this viewpoint they would seem to contribute to the consolidation of essentialist positions with regard to nationality, religion, politics or culture, in other words, to identity. In terms of content, they end in a final pessimistic note, resulting from a deterministic atmosphere in which characters are doomed to dissatisfaction. None of the authors chosen for this discussion are professional thriller writers, although, in one way or another, they have all experimented with the form and their names are well known in (Northern) Irish literary circles. Their "Troubles" thrillers have been concerned with the exploration of moral, psychological and social preoccupations that were ignored in the most popular and traditional mode. ${ }^{8}$

As will be explored below in more detail, the "Troubles" thriller presents the following traits: the inclusion of actual or realistic political facts; the portrayal of characters who feel, one way or another, responsible for the social, political or historical contradictions of society, the resolution of which would turn them into heroes; the depiction of the conflict in terms of pressure of the community on the individual; and the exploration of questions of identity. As within these novels the nature of the criminal actions is not analysed, these appear as the inevitable result of a chain of historical events and merely serve to perpetuate violence. Readers do not have the experience of eventually participating in the resolution of a crime nor are they left with a feeling of satisfaction. From this perspective, then, it seems valuable to explore the ways in which the "Troubles" thriller both differs from the traditional mode and addresses, through the inclusion of specific symbols and imagery, notions of identity as stable categories. Significantly, the evolution of the thriller has paralleled a growing trend within contemporary Irish literature - North and South - that concerns itself with the destabilisation of binary notions, problematizing and blurring categories with regard to all kind of boundaries - national, geographical, sexual, racial or cultural - stressing ultimately difference and hybridisation. ${ }^{9}$

In the present discussion my main concern is not so much with the plot, that is, the story of the individual or of the society it presents, but rather with the meaning that some representational codes acquire and with the important role they play in a society where signs prevail over facts and where the "Troubles" seem fated never to find a resolution. It is significant to decode the symbols that construct these discourses because, as Davies suggests: "To study a popular genre is to study lived social relations, not because popular fictions transparently 'reflect' those relations but because the meanings and structures of their narratives are 'actively attributed' by their readers - among whom, of course, must be numbered their writers, and ourselves, who study them" (1989: 131). Symbols are created for the transmission of a certain ideology and, especially in Northern Ireland, to set up boundaries that demarcate different sectors. The literature produced in this region echoes this reality through the construction of a discourse in which symbols, colours, murals, banners, graffiti, bonfires, parades and other marks of political or religious identity are used to position characters and attitudes into clear-cut categories.

Kiely's Proxopera ${ }^{10}$ is a sentimental melodrama about the kidnapping of a family by three IRA men, who force the elderly and sick Mr Binchey, a retired teacher of history and classics, to drive a time-bomb to the house of Judge Flynn - according to the narrator, "one of the best men in the north" (1977: 78). This novel, published in 1977, is a product of the earlier stage of the conflict, in which the reader encounters striking pastoral imagery of peace and a romanticization of the land. ${ }^{11}$ This contrasts with a parallel discourse, appearing now and then written in italics, which presents images of violence and destruction. The idyllic and idealised landscape, witness to the events, is eventually made accomplice and victim of the crimes. Being part of Northern Ireland, nature cannot avoid the "Troubles": "... murderers in the dark had made the sleeping lake their accomplice. The innocent lake had been forced to share the guilt. The lake, out there and fading into another dusk, the lake knew. It could never be the same again" (1977: 31). Although the novel recounts a terrorist 
action carried out by the IRA, Protestants are seen in no better light. Violence is thus portrayed as endemic, perpetuated by both groups in a never-ending retaliation for each other's crimes. Against this atmosphere, the protagonist's dreamed lake house, symbolically painted in white, is built in an all-too harmonious nature. In opposition to this, references to the "Orange hall" together with ironic allusions to the marching of the Orange order - "July was the best month for perch and the best day was the twelfth" (1977: 12-13) are constant. The entire novel is tinged with references to the green hills, clear water and Orangemen, in clear allusion to the Irish flag. This points to the violent sectarianism of the village by means of the colour symbology: "There were other houses, Orange and Green or Protestant and Catholic, on the hills around the lakeshore, but they were simple thatched cottages and nothing at all in the baywindowed, wide-fronted style of the white house" (1977: 15). At the end, this white house, placed in between the green hills and the orange houses, becomes not the symbol of union and peace but of destruction and death. ${ }^{12}$ As the protagonist says, then, what has been shattered is more than his family or his town, it is "[his] dream of a white house" (1977: 92) and, with it, the possibility of an end to the conflict. It is perhaps for this reason that the novel, with its romanticising vision of the land and nostalgia for a better past, blemished now by the atrocities of sectarian violence, is dedicated, as the book opens, to the "Memory of the Innocent Dead" (1977: 7).

Brian Moore's Lies of Silence is also a political and psychological thriller that takes a similar event as its subject matter. ${ }^{13}$ The protagonist's wife has been taken hostage by an IRA group and he is forced to plant a bomb in one of the most important hotels in Belfast if he is to save her life. Although in the two novels neither the protagonists nor the settings have much in common, both narratives revolve around the dilemma the main characters have to confront. They are torn between their responsibilities to protect and save their families, which would force them to participate in terrorist activities, and their duty toward society, which sees such actions as simply wrong. In Lies of Silence, published almost two decades after Proxopera, we find a marked contrast to the idealised surroundings of the earlier novel since it portrays a more realistic
Belfast in which sectarianism is seen as a reflection of the existence of two social classes rather than of two violent groups. The novel offers a clear depiction of "those parts of Belfast which had become the image of the city to the outside world: graffiti-fouled barricaded slums where the city's Protestant and Catholic poor confronted each other, year in and year out, in a stasis of hatred, fear and mistrust" (1992: 21). However, the protagonist Dillon knows that where he lives, "in the north end of Belfast", away from the ghettos, there is no such distinction since: "Protestants and Catholics lived side by side, joined by class, by economic ties, even by intermarriage, in a way the poor could never be" (1992: 22). In this sense, one could say that Moore's thriller focuses on the deeper political aspects that lie beneath the apparently unquestionable bigotry of both groups. Considering his young criminal captors to be dangerous victims of the failure and negligence of politicians, Dillon goes on to blame the lies that sustain this atrocious reality:

Dillon felt anger rise within him, anger at the lies which had made this, his ... birthplace, sick with a terminal illness of bigotry and injustice, lies told over the years to poor Protestant working people about the Catholics, lies told to poor Catholic working people about the Protestants, lies from parliaments and pulpits, lies at rallies and funeral orations, and, above all, the lies of silence from those in Westminster who did not want to face the injustices of Ulster's status quo. (1992: 69-70)

If Proxopera highlighted a violent sectarian society as being the product of history, Lies of Silence pictures a reality in which Catholic and Protestant ghettos coexist side by side with areas where people are completely unaware of the socio-economic injustices that underlie the "Troubles". In fact, as Dillon thinks: "Ignoring the trouble was an Ulster tradition. Another wee bomb, as the local joke had it. By next week the whole incident would be forgotten" (1992: 110). At the end of the novel he therefore comes to the conclusion that doing away with the IRA will not bring the conflict to an end. Until Catholics and Protestants share the same opportunities with regard to housing, employment and power the "Troubles" will go on: "And the only ones who can force them into it are the British Government. Who haven't got the guts" (1992: 196-97). 
Divorcing Jack, Colin Bateman's action thriller, offers an alternative vision to the gloom and bleakness of the Northern-Irish reality that has been habitually conveyed. It is set in Belfast, although its standpoint is the Protestant side, and it approaches the "Troubles" from a humorous perspective. Playing with tragedy and comedy, the author manages to build a story grounded on absurd situations exaggerated to the point of farce, which makes the novel "the first "comedy thriller' dealing with the "Troubles" (Smyth 1997: 123). Dan Starkey is a Protestant journalist, well-known for his wit and his satirical and sarcastic humour, who, involuntarily, finds himself involved in a sequence of events that leads to the murder of his recent lover Margaret - the daughter of a politician - and to the kidnapping of his wife. In this novel, the reality of the "Troubles" is also exposed to the eyes of an outsider, the American journalist Charles Parker, who is on a special programme to cover the elections for a Northern Irish government and gather information about the conflict. ${ }^{14}$ Starkey takes him on "the usual terror tour, up the Falls Road to see the Republican wall murals, up the Shankill to see the Protestant equivalent" (1995: 46). The frivolous humour with which the protagonist refers to sectarianism is constant throughout the novel. From the very first pages, Starkey seems to take the "Troubles" rather lightly: "I had this idea about swapping the terrorist wasteland of West Belfast for the Guinness Brewery in Dublin. They could have our troubles and we could drink theirs" (1995: 4). Terrorism seems to be so habitual that it shapes the routines of everyday life. In the city, taxi drivers refuse to enter certain streets that are too risky, people are searched in shops for security reasons, and nobody seems to be bothered about it. In this atmosphere of commonplace violence it comes as a surprise that the Prime Minister to be, Mark Brinn, is the leader of the "Alliance Party", whose political programme represents a compromise between Unionists and Nationalists; in other words, a promise of hope for Northern Ireland (49). However, as the novel will finally reveal, his campaign for peace is as false as his own life. Brinn became a peacemaker politician after having been a member of an IRA unit responsible for the bombing of a restaurant, which caused the death of eight people. In his final attempt to conceal his past he resorts to bribery and plants a bomb to kill a con man who is blackmailing him. At the same time, the latter, anticipating such an exploit, also plants a bomb and kills Brinn. Ironically, these acts, which result in the death of both the ex-terrorist and the IRA gangster, take place on the day of the elections. Their outcome is the success of the "Alliance party", whose programme has been mockingly presented as: "Power sharing, a largely autonomous state, freeport status, British but not British, Irish but not Irish. Independence with a safety harness. A Northern Irish Hong Kong really. Ideas that seem to be generally popular" (1995: 88). Under this light, it would seem that Divorcing Jack locates the "Troubles" at the level of a tribal war between Catholics and Protestants although, as I am trying to suggest, these three "Troubles" thrillers offer a much more complex discourse than one merely contrasting binary positions with regard to ideologies, characters or settings.

In their representation of conflict the three novels differ significantly from the traditional thriller. This is true also with regard to the portrayal of characters. Within the conservative ideology of the traditional thriller with its classical "goodies" and "baddies", the protagonists, according to Palmer, should have an isolated and competitive personality that will eventually prove them "better adapted to the world than everyone else .... What the thriller does, essentially, is to explore the various ramifications of the proposition, common enough in our society, that the individual must be competitive in order to be an individual" (1989: 194). In most traditional thrillers there is a conspiracy or a threat that the heroes have to confront and resolve. They need to demonstrate that they are different and superior to the rest and, above all, to the evil forces that menace society. In these "Troubles" thrillers, however, the outcome turns out differently. Heroes do not triumph over evil in any unequivocal way, and even where - as is the case of Mr Binchey - they succeed to some extent, they still leave the reader with a sense of unease. Of the three main characters discussed, both $\mathrm{Mr}$ Binchey and Dillon are apolitical, while Dan Starkey is not. Moreover, all are outsiders: a retired teacher dissatisfied with the reality of his village, a hotel manager who dreams of the day when he will leave Ireland, and a Unionist journalist who is only 
prepared to commit to his ideology after being put under pressure by Republican pretensions of unification. None of them are willing to have anything to do with the Northern Ireland's conflict and it is only circumstances that oblige them to. In all three cases, they are subject to forces outside their control.

Trying to find the source of the uncontrollable violence that rules his village, Mr Binchey in Proxopera asks himself who "guided or misguided" (Kiely 1977: 84) these young people. The only answer he can find is: "Ireland. A long history. England. Empire. King William. The Pope. Ian Paisley. Myself. I was a teacher of history" (1977: 84). Having devoted his entire life to teaching (this) history, he cannot avoid feeling responsible for the (re)creation of the national myths that have fuelled the perpetuation of sectarian violence. His age, and his dream of the white house that symbolises unity, make him refuse to yield to the power of the IRA and, instead of driving the bomb to the indicated target, he reports it to a British check-point, becoming then "after all a hero" (1977: 86). However, on turning informer he has to pay the price and the IRA retaliates by burning down his white house and kneecapping his son. Although Pelaschiar argues that Proxopera is one of the few "Troubles" novels that does not end tragically since, at the end, order is restored and justice prevails (1998: 77), this does not seem convincing as the reader cannot feel reassurance with the punishment of the criminals. On the contrary, the novel all along has conveyed the message that endemic violence has divided this society into good and evil.

The protagonist of Moore's Lies of Silence, like the other protagonists, is an antihero, a frustrated and "failed poet in a business suit" (Moore 1992: 12), whose position as manager of a hotel does not make up for the empty and monotonous life he shares with his wife Moira. In the novel, he has to face a similar dilemma to Mr Binchey's, though, in this case, Dillon also has to decide whether to tell his wife Moira of his plans to move to England with his young lover Andrea. In addition to this, like Binchey he is blackmailed into planting a bomb in his hotel, and has to choose whether to save the life of his kidnapped wife or to do his duty as manager saving the lives of hundreds of people. In the end, his actions are unheroic, like those of the other protagonists.
In the reality of the Belfast of the eighties bombs are part of daily life, as the security system of the hotel, bombed only the previous year, reveals (1992: 12). In his attempt to become a hero - but also trying to evade his personal struggle - he tries to save both his wife and the guests in the hotel and succeeds. The bomb has gone off but has only damaged some parts of the building and his wife has been released by the IRA, which had assumed he would comply with their demands. When his mission has ended, he exchanges Belfast for London but, having become an informer like old Mr Binchey before -, he eventually encounters his own death at the hands of IRA terrorists, who have followed him to England to punish his disobedience.

In Divorcing Jack, Starkey identifies himself as a "Unionist with a sense of humour" who does not support terrorism (Bateman 1995: 9). Although he is the only protagonist of the three books who has a clear ideology, he is not willing to fight for any cause, let alone become a hero. Starkey is in fact an antihero who gets involved in the most absurd situations, drinks heavily, is seduced by several women, and seems to constantly find himself in the wrong place, at the wrong time and with the wrong sort of people. When he finally manages to save his own life, it has only been a matter of chance. Although the book ends in partial hope due to the fact that a new government will rule Northern Ireland, it is clear that the civil war will go on while Starkey witnesses the bombing of the two cars and watches "the smoke from infernos at either end of the road rise and mingle high up in the blue" (1995: 268). On the one hand, as Smyth suggests, the significance of Bateman's novel can be perceived in its attempt to free the Protestant Unionist tradition "of its image as a narrow reactionary culture and reveal itself instead as a complex and subtle modern identity" (1997: 125). ${ }^{15}$ On the other hand, Divorcing Jack imparts a similar approach to sectarianism as the previous two novels, in the sense that the "war" is not primarily presented as the result of and, indeed, a reaction to violence but rather as a way to justify its perpetuation. Binchey's son says in Proxopera to one of the IRA men: "Man, you love the Brits, you couldn't exist without them .... They give you the chance to be Irish heroes. They give you targets you can easily see" (Kiely 1997: 27). Similarly, Moira in Lies of 
Silence tells the IRA men that they cannot make anyone believe they fight for the freedom of anyone, and it is instead hatred that motivates them, since "if the Catholics here stopped hating the Prods, where would the IRA be?" (Moore 1992: 62).

The North of Ireland, divided by questions of political and cultural identity, has inevitably transposed its own preoccupations onto a literary discourse that plays with archetypal struggles and stereotyped characters and situations to appeal to the reader through the thrill of its own narrative. The reading of these three texts shows that the Northern Ireland discourse reflects the cultural identity of its own people, an identity which is as different to that of the Irish of the Republic as to that of the British, one that presents division and conflict as the norm. Seamus Deane has shared this view that Northern Irish people feel "neither Irish nor British while also being both" (1983: 45-46). Dermot Bolger, in his introduction to The Picador Book of Contemporary Irish Fiction, has claimed as well that statistical analysis carried out at the beginning of the nineties shows that people from the Irish Republic "feel now that they have more in common with the Scottish, Welsh and English than with any section of the population in the North" (1993: ix). The term "Northern" serves then not only as a mark with which to denote a geographical boundary but as an arbitrary space in which binary notions of identity coexist together with a plurality that is increasingly attempting to blur dual categories with regard to nationality, religion and politics. ${ }^{16}$ In Divorcing Jack, Dan Starkey wittily explains to the American journalist that there are different terms to refer to the tricky identity of the area: "If you're a Loyalist you'll call it Ulster, if you're a Nationalist you call it the North of Ireland or the Six Counties, if you're the British Government you call it the Province". Parker then asks him what he calls it, to which Starkey answers: "Home" (Bateman 1995: 46). Likewise, in Lies of Silence, Dillon, who despises Ireland, recognises at some point that no matter where he moved, he would always know that Northern Ireland was home because it would be the only place where he would not feel a stranger (Moore 1992: 199). Consequently, it can be argued that Northern-Ireland fiction, and especially its most popular mode, stands out as a regional category from which writers and artists both articulate and resist notions of stable and fixed identities, a fact that the three novels of this discussion illustrate.

Notes

1 This article, with slight variations and a different title, was originally sent to the volume National and Cultural Identities in Contemporary Detective Fiction, edited by Marieke Krajenbrink and Kate Quinn, within the series "Textxet. Studies in comparative literature", to be published by Rodopi. Since there seems to be some problems with the final outcome of the book, the general editor of the collection, Theo D'haen, has granted me permission to publish my study elsewhere given the nature of such a time-sensitive subject. This text is, therefore, a version conceived four years ago when I was commissioned to write it, to which I have now added some minor changes and a few details to update it.

${ }^{2}$ The research carried out for the writing of this paper has been financed by the Spanish Ministry of Education (DGICYT, research project HUM2004$02413 /$ FILO) and by the University of Alcalá (Vicerrectorado de Investigación, research project UAH PI2004/020).

${ }^{3}$ Different dates have been given to refer to the origin of the "Troubles". In August 1966 there were celebrations of the fiftieth anniversary of the Easter Rising 1916, which caused some disturbances between Protestants and Catholics. Also in 1968 the Royal Ulster Constabulary intervened violently in a demonstration in favour of the civil rights. However, 1969 was the year when British troops became involved in the civil strife. See also Deutsch (1975-76: 131) and Graham-Yooll (1994: 289) for the euphemism associated to the current meaning of the term "Troubles".

${ }^{4}$ Chandler, in his famous essay "The Simple Act of Murder" (1980), deals with detective and mystery fiction in general. Todorov establishes a clearer distinction between the thriller - the série noire -, the whodunit and a third category that has developed between these two forms, which is the suspense novel (1988: 161-63). Fowler adds that the British term "detective story" and the American "mystery" are not the same at all, "the latter merges easily into the thriller of Hammett, Chandler, or Macdonald, whereas the former remains sharply distinct. Neither the thrillers of Fleming nor the entertainments of Greene could possibly be taken for detective stories" (1982: 133).

5 For a comprehensive bibliography of works of fiction related to the "Troubles", see the following: Bill Rolston's compilation at http://cain.ulst.ac.uk/ bibdbs/fiction.htm, which is periodically updated; Patrick Magee's book Gangsters or Guerrilla? (2001), which provides a longer and more detailed list including short stories and which can also be 
seen at http://cain.ulst.ac.uk/bibdbs/magee01/index.html\#appenda; and the recent study by Aaron Kelly, The Thriller and Northern Ireland since 1969 (2005), which adds more titles.

${ }^{6} \mathrm{He}$ is referring to novels such as World Without End, Amen (1954) by Jimmy Breslin; Harry's Game (1975) by Gerald Seymour; Interface Ireland (1979) by Kevin Dowling; and Bitter Orange (1979) by Des Hamill (1980: 114). See Kennedy-Andrews' chapter “The Troubles as Trash", included in his study Fiction and the Northern Ireland Troubles since 1969: (de-)constructing the North (2003), for a more recent and detailed analysis of these type of novels.

${ }^{7}$ According to Deutsch, this is a general characteristic of the first stage of the "Troubles" fiction and not only of the thriller (1975-76: 149). See Pelaschiar for a commentary of an interview with the criminologist Bill Rolston, who manifests his worries for the revitalisation of a form that reduces the cultural identity of Northern Ireland to a group of violent "macho-men" terrorists (1998: 20). See also my own article about Northern-Irish literature in the political atmosphere of the "Troubles" (2000).

${ }^{8}$ Among the three, Brian Moore has been the most prolific and experienced since he has also published popular thrillers under pseudonym. In an interview, he admitted to have discovered that a narrative form like the thriller, mainly left for second-rate writers, was "tremendously powerful ... the gut of fiction" (Tóibín 2000: 8). Lies of Silence was shortlisted for the Booker Prize in 1990. Colin Bateman, who was a journalist before he became a writer, is the most popular of the three authors of this discussion. He has published other thrillers, although not necessarily set in Northern Ireland. With his first novel, Divorcing Jack, he was awarded the Betty Task Prize in 1994. Benedict Kiely is probably the most established of the three. Proxopera is one of the first attempts to narrate the dynamics of the "Troubles", which would be followed later by Kiely's Nothing Happens in Carmincross (1985).

${ }^{9}$ I would like to point, in this respect, that the last Conference of AEDEI (the Spanish Association for Irish studies) celebrated in Tarragona in May 2005, centred precisely on the theme of "Re-writing boundaries". See the forthcoming proceedings edited by Cristina Andreu for a variety of perspectives that were discussed there.

${ }^{10}$ The term "proxopera" refers to "the practice of hostage-taking and the coercion of sibilinas into delivering carbombs" (Sampson 1998: 276). In the novel, the protagonist comments ironically on the "operation by proxy" type of crime: "Not even the Mafia thought of the proxy bomb, operation proxy, proxopera for gallant Irish patriots fighting imaginary empires by murdering the neighbours" (Kiely 1977: 58).

11 In this respect, Proxopera bears some similarities with earlier novels of the "troubles", which explored pastoral images, nostalgia for the past and an idealisation of the land. See a recent discussion of this aspect in Praga (2005: 223-32).

12 Besides, according to Buckley, "there is much more to symbolism than just politics and power. Symbols are also a means through which people clarify the world" (1998: 2).

${ }^{13}$ Although it might seem that Moore's story grew from Kiely's, he explained that the plot was based on a real event he himself experienced in 1987, when he was going to receive his doctorate: "I was in the Wellington Park Hotel, near Queen's University, and we had a bomb scare in the middle of the night. We were all put out in the street, and I saw these French tourists there. I was listening to them, and they hadn't the slightest idea what was happening. So I thought about what happened and wondered about what it would have been like if they were killed and they didn't know who killed them" (qtd. by Sampson 1998: 276).

14 This element of the plot anticipated the establishment of such a body in reality with the first Stormont Assembly being elected in 1999.

${ }^{15}$ Pelaschiar shares the same opinion, adding to it that: "Not only has Bateman's ironic, irreverent and highly entertaining writing voiced a new perception of Northern Irish reality from a moderate unionist point of view, but in voicing it in such an unorthodox way it has also contributed to destabilizing the conventional vision of Northern Irish Protestants as reactionary, bigoted, unimaginative and narrow-minded" (1998: 24).

${ }^{16}$ Corcoran adds that from the late nineteen sixties "writing from the North of Ireland has come to be widely regarded as among the most significant contemporary work in the English language" (1997: 131). On the other hand, Harte and Parker argue that the Northern Ireland strife has led to the enunciation of revisionist positions towards literature, history and culture that have come from the Republic (2000: 4).

\section{Works Cited}

Bateman, Colin. 1995. Divorcing Jack. London: HarperCollins.

Bolger, Dermot. 1993. "Introduction". The Picador Book of Contemporary Irish Fiction. Ed. Dermot Bolger. London: Picador. vii-xxvi.

Bowyer-Bell, J. 1978. “The Troubles As Trash”. Hibernia (20 January): 22.

Buckley, Anthony D. 1998. "Daring Us to Laugh: Creativity and Power in Northern Irish Symbols". Symbols in Northern Ireland. Ed. Anthony D. Buckley. Belfast, Institute of Irish Studies: Queen's Univ. of Belfast. 1-21. 
Chandler, Raymond. 1980. “The Simple Art of Murder”. Pearls are a Nuisance. London: Penguin. 181-99.

Corcoran, Neil. 1997. After Yeats and Joyce: Reading Modern Irish Literature. Oxford and New York: Oxford UP.

Davies, Tony. 1989. “The divided gaze: Reflections on the political thriller". Reading Popular Fiction: Gender, Genre and Narrative Pleasure. Ed. Derek Longhurst. London: Unwin Hyman. 118-35.

Deane, Seamus. 1983. "The Artist and the Troubles". Ireland and the Arts. Ed. T. P. Coogan. London: Namara. $42-50$.

Deutsch, Richard. 1975-76. "Within Two Shadows': The Troubles in Northern Ireland". The Irish Novel in Our Time. Ed. Patrick Rafroidi and Maurice Harmon. Lille: Publications de 1'Universite de Lille III. 131-54.

Fowler, Alastair. 1982. Kinds of Literature: An Introduction to the Theory of Genres and Modes. Cambridge, Mass: Harvard UP.

Glover, David. 1989. "The stuff that dreams are made of: Masculinity, femininity and the thriller". Reading Popular Fiction: Gender, Genre and Narrative Pleasure. Ed. Derek Longhurst. London: Unwin Hyman. 6783.

Graham-Yooll, Andrew. 1994. "Belfast, 20-23 October 1993”. The Antioch Review 52,2 (Spring): 286-96.

Harte, Liam, and Michael Parker. 2000. "Introduction”. Contemporary Irish Fiction: Themes, Tropes, Theories. Ed. Liam Harte and Michael Parker. London: Macmillan. 1-12.

Jeffery, Keith, and Eunan O’Halpin. 1990. "Ireland in Spy Fiction”. Intelligence and National Security (October): 92-116.

Kelly, Aaron. 2000. "AA Stasis of Hatred, Fear and Mistrust'. The Politics of Form in Representations of Northern Ireland produced by the 'Troubles' Thriller". New Voices in Irish Criticism. Ed. P. J. Mathews. Dublin: Four Courts. 109-15.

2005. The Thriller and Northern Ireland since 1969: Utterly Resigned Terror. Aldershot: Ashgate.

Kennedy-Andrews, Elmer. 2003. Fiction and the Northern Ireland Troubles since 1969: (de-)constructing the North. Dublin: Four Courts P.

Kiely, Benedict. 1977. Proxopera: A Novel. London: Victor Gollancz.

Magee, Patrick. 2001. Gangsters or Guerrillas? Representations of Irish Republicans in “Troubles Fiction”. Belfast: Beyond the Pale, 2001.

2005. "Appendix A: Category (a) novels by year of first publication". Available at: http://cain.ulst.ac.uk/bibdbs/magee01/index.html\#appenda.

McMinn, Joe. 1980. "Contemporary Novels on the Troubles". Etudes Irlandaises 5. 113-21.

Moore, Brian. 1992 (1990). Lies of Silence. London, Vintage.

Morales, Marisol. 2000. "La literatura norirlandesa actual en el panorama político de los 'Troubles"”. Márgenes y centros en la literatura británica actual. Ed. Fernando Galván Reula. Alcalá: Servicio de Publicaciones de la Universidad. 147-94.

Palmer, Jerry. 1989. "Thrillers: the Deviant Behind the Consensus". The Study of Popular Fiction: A Source Book. Ed. Bob Ashley. London: Printer Publishers. 186-95.

Patten, Eve. 1995. "Fiction in Conflict: Northern Ireland's Prodigal Novelists". Peripheral Visions: Images of Nationhood in Contemporary British Fiction. Ed. Ian A. Bell. Cardiff: U of Wales P. 128-48.

Pelaschiar, Laura. 1998. Writing the North: The Contemporary Novel in Northern Ireland. Trieste: Edizioni Parnaso.

Praga Terente, Inés. 2005. "La novela del Norte". La novela irlandesa del siglo XX. Barcelona PPU, $207-61$.

Rolston, Bill. 1989. "Mothers, Whores and Villains: Images of Women in Novels of the Northern Ireland Conflict". Race \& Class 31,1. 41-57.

2005. "A Bibliography of Works of Fiction Relating to 'the Troubles"'. Available at: http://cain.ulst.ac.uk/bibdbs/fiction.htm.

Sampson, Denis. 1998. Brian Moore: The Chameleon Novelist. Dublin: Marino Books.

Smyth, Gerry. 1997. The Novel and the Nation: Studies in the New Irish Fiction. London: Pluto P.

Todorov, Zvetan. 1988. "The Typology of Detective Fiction". Modern Criticism and Theory: A Reader. Ed. David Lodge. London and New York: Longman. 158-65.

Tóibín, Colm. 2000. “Gaelic Gloom”. London Review of Books 22,15 (10 August): 3-8.

Williams, Linda R., ed. 1992. The Twentieth Century: A Guide to Literature from 1900 to the Present Day. London: Bloomsbury Publishing Ltd. 